\title{
Streamlining Business Process: a Case Study of optimizing a business process to issue a letter of assignment for a lecturer in the University of Surabaya
}

\author{
Jimmy \\ the University of Surabaya, Department of Computer Science, Surabaya, Indonesia \\ Corresponding E-mail: jimmy@staff.ubaya.ac.id
}

\begin{abstract}
This paper focused on revealing how a business process can be streamlined by thoroughly examined a case study of a project to optimize a business process to issue a letter of assignment in the University of Surabaya (Ubaya). The case study shows evidences on how the university could successfully deliver significant benefits by utilizing IT to optimize a business process. It shows how Trkman's success factor framework can be used as a guideline to implement a business process improvement project in a higher education institution.
\end{abstract}

Keywords: Business process $\cdot$ improvement $\cdot$ success factor

\section{Introduction}

Business process is a system which consists of activities performed by various employees from a set of diverse units in an organization [1]. It represents how an organization works and thus, determines the organization's affectivity and efficiency. Efforts made to streamline business process, which has also been known as business process reengineering (BPR) and business process management (BPM), can be considered as "the fundamental rethinking and radical redesign of business processes to achieve dramatic improvements in critical measures of performance such as cost, quality, service, and speed" [2][3].

Such potential has lured most firms to conduct BPR [4]. Unfortunately, streamlining business process is not an easy task, various researches suggest that BPR project are an extremely high risk project where only $30 \%$ of those initiatives are able to successfully deliver the expected results [5][6][7]. Such facts suggest that despite the tempting advantages, BPR is a complex project which should be engaged carefully to harvest the expected outcomes. 
This paper attempts to reveal how a business process can be streamlined by thoroughly examines a case study of a project done by the University of Surabaya to optimize a business process to issue a letter of assignment. Other than attempting to optimize the business process, the project is also a pilot project to measure the organization's readiness towards a computer based approval system.

\section{Literature Review}

\subsection{Measuring Success}

Prior thoroughly analyzing the case study, it is important to firstly measure the project's success since a success story offers different kind of lessons than a disastrous story. This paper will use the four dimensions model of process redesign effects as proposed by Brand and Van der Kolk [9] to measure the success level of the case study. The model compares the business process' performance before and after the improvement on four dimensions: cost, quality, time, and flexibility. Achieving maximum results on all dimensions is unlikely as each dimension might contradict other dimensions and thus often lead to trade-off that has to be made when streamlining a business process.

\subsection{Success Factors of Business Process Improvement Project}

One way to reveals lessons behind the success story is by confirming the case with literatures regarding key success factors of business improvement project. For this purpose, Trkman [8] proposed a framework which classified the success factors into three distinct groups: contingency theory, dynamic capabilities and task-technology fit.

The contingency theory focuses on fitness between the business process and the business environment. Secondly, dynamic capabilities refer to continuous improvement to assure sustained benefits from streamlining the business process. Lastly, task-technology fit focuses on fitness between IT and the business process.

\section{The Case Study}

The case study is an initiative from Ubaya to streamline the process to issue letter of assignment to lecturer who wants to present his/her paper in a conference. Although, this process is not a major process in the university, it plays a critical role as paper publishing is an important task that needs to be done by every lecturer in a university. The number of publication produced by a lecturer directly affects performance appraisal of the lecturer, the lecturer's department and the university. 


\subsection{Analysis of the Previous Process}

Legacy process to issue the letter of assignment in Ubaya involve the use of traditional paper based procedures with no suffice documentation procedure. The use of paper forms has caused many redundant processes needs to be done by various stakeholders. The redundancy and the nature of paper based systems contribute to the lengthy time required to issue the letter of assignment. Figure 1 shows flows of the legacy process using the BPMN (i.e. Business Process Mapping Notation).

Further, the biggest problem with the legacy system occurred after the lecturer accomplishes the given assignment. Although data about published papers is required by various units, there was no clear decision towards who and how should the published paper be documented. Therefore, whenever data about publication is required, unit which requires the data will conduct survey to all lecturers to gather information about their publications. On top of that, important evidences regarding the publications often went missing with no possible way to recover it.

\subsection{Implementation of the new process}

The new process is designed to overcome the many issues in the legacy process. By utilizing the integrated information systems owned by the University of Surabaya, the new process is expected to be able to solve problems regarding documentation and publication data query.

The process optimization project is initiated by the Vice Rector of academic by gathering all stakeholders who often require the publication data and the IT department which is expected to deliver the required systems. One of the most important decisions produced in the gathering is decision regarding authority of the publication data which will be held by the center of research. Another important decision is decision to streamline the business process using IT as a catalyst to solve various issues of the old process. Figure 2 shows the new business process mapping.

All tasks in the new system were designed to be done using the university's portal including the generation of the signed letter of assignment. Signatures and stamps of all deans and the vice rector were collected, scanned, and stored in the server to be used to generate the letter of assignment. Approvals could review and decide to accept or reject the proposed assignment via internet at their convenient time and location. Further, the system also stores all necessary documentation regarding the publications. Thus, publication data along with the related documentation can be easily accessed by any authorized stakeholders. 


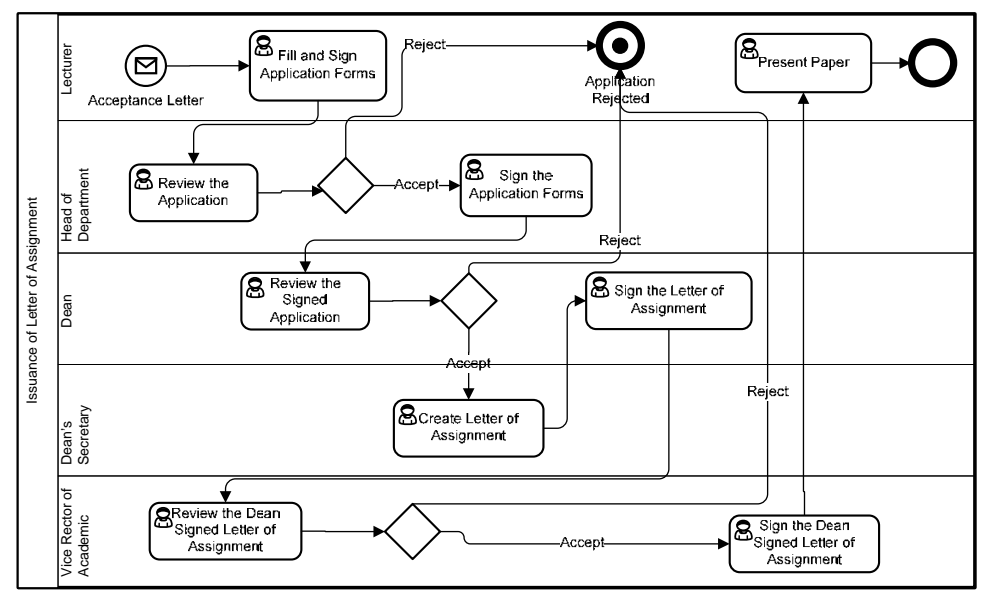

Figure 1. The legacy business process

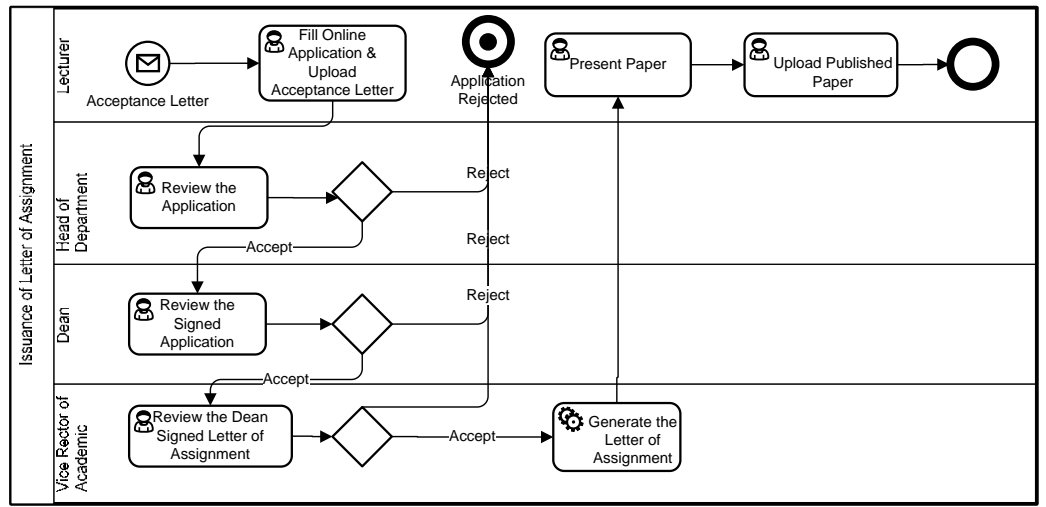

Figure 2. The new business process

\section{Results and Discussion}

This section seeks to justify the case's success using the four dimensions as described in the literature review. Comparison of the old and new processes on each dimension is described in Table 1.

Table 1. Comparison of the old and new processes

\begin{tabular}{|l|l|l|}
\hline \multicolumn{1}{|c|}{ Old Process } & \multicolumn{1}{c|}{ New Process } \\
\hline \multirow{5}{\tilde{\delta}}{} & $\begin{array}{l}\text { Requires application forms, re- } \\
\text { quires Dean's secretary to write } \\
\text { letter of assignment, requires effort } \\
\text { to collect publication data }\end{array}$ & $\begin{array}{l}\text { No application forms, letter of as- } \\
\text { signment is generated by the sys- } \\
\text { tem, easy and instant access to pub- } \\
\text { lication data }\end{array}$ \\
\hline
\end{tabular}




\begin{tabular}{|l|l|l|}
\hline & $\begin{array}{l}\text { No clear documentation proce- } \\
\text { dures, no publication database, fre- } \\
\text { quent redundant questionnaires } \\
\text { about publication irritates lecturers }\end{array}$ & $\begin{array}{l}\text { Centralized publication database } \\
\text { available conveniently for any au- } \\
\text { thorized stakeholders, no publica- } \\
\text { tion questionnaires }\end{array}$ \\
\hline $\begin{array}{l}\text { Days to get the letter of assignment } \\
\text { approved, weeks to collect publica- } \\
\text { tion data from lecturers, hours to } \\
\text { collect publication documentation }\end{array}$ & $\begin{array}{l}\text { Head of department, Dean, and Vice } \\
\text { Rector could approve immediately } \\
\text { even when they are out of office, in- } \\
\text { stant access to publication data }\end{array}$ \\
\hline $\begin{array}{l}\text { Require physical contacts for ap- } \\
\text { proval, required to reach all lectur- } \\
\text { ers to collect publication data }\end{array}$ & $\begin{array}{l}\text { Instant approval via internet, publi- } \\
\text { cation data stored in server available } \\
\text { for authorized users at any time }\end{array}$ \\
\hline
\end{tabular}

Table 1 evidently shows that the new process is superior to the old process on all four dimensions. The new system is proven to be more cost effective, able to deliver better stakeholders' experience, able to provide a better quality of publication data, more cost effective and more flexible than the old processes. Therefore, the project to optimize the business process to issue the letter of assignment can be considered as successful.

After confirming the case's success, the Trkman's framework of key success factors in business process improvement will now be used to reveal how Ubaya could successfully streamline the business process (see Table 2)

Table 2. Evidence of key success factors in the case

\begin{tabular}{|c|c|}
\hline \multirow{4}{*}{ 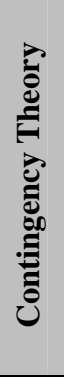 } & $\begin{array}{l}\text { Strategic alignment: Publication is critical for lecturers to leverage their } \\
\text { carrier. The publication data is also required as a major indicator in the } \\
\text { university's and department's accreditation. }\end{array}$ \\
\hline & $\begin{array}{l}\text { Level of IT investment: Business owner in Ubaya should prepare a suffice } \\
\text { amount of investment based on the Directorate of Information System ad- } \\
\text { vise to ensure appropriate level of IT investment. }\end{array}$ \\
\hline & Performance measurement: as described in Table 1. \\
\hline & $\begin{array}{l}\text { Level of employee's specialization: The new system eliminates the exist- } \\
\text { ence of staff that specializes in writing letter of assignment and collecting } \\
\text { publication data. }\end{array}$ \\
\hline \multirow{4}{*}{ 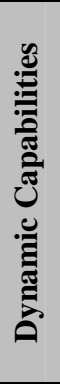 } & $\begin{array}{l}\text { Organizational changes: The new system does not change existing organ- } \\
\text { izational structure but confirming the authority of publication data to the } \\
\text { center of research department. }\end{array}$ \\
\hline & $\begin{array}{l}\text { Appointment of process owners: All stakeholders were gathered to gain } \\
\text { consensus on how the new process ideally works. Progresses are reported } \\
\text { to gain feedback from all stakeholders. }\end{array}$ \\
\hline & $\begin{array}{l}\text { Implementation of proposed changes: The University preferred to deliver } \\
\text { quick wins by deploying several small projects. Project in this paper's case } \\
\text { is the pilot project with several other sequencing projects. }\end{array}$ \\
\hline & Use of a continuous improvement systems: Ubaya held regular cross sec- \\
\hline
\end{tabular}




\begin{tabular}{|l|l|}
\hline & $\begin{array}{l}\text { tional meetings to ensure any units are aware of the latest regulations and } \\
\text { improvements }\end{array}$ \\
\hline \multirow{3}{*}{$\begin{array}{l}\text { Processes standardization: Business process is agreed at the university } \\
\text { level which applied consistently across all faculties. }\end{array}$} & $\begin{array}{l}\text { Informatization: The new system used less paper but still allow user to } \\
\text { print any necessary documents when needed. }\end{array}$ \\
\cline { 2 - 3 } & $\begin{array}{l}\text { Automation: The new system automatically generates the letter of assign- } \\
\text { ment after the Vice Rector approval. }\end{array}$ \\
\cline { 2 - 3 } & $\begin{array}{l}\text { Training and employee's empowerment: The new system is introduced } \\
\text { and trained to all representatives from faculty before officially launched. }\end{array}$ \\
\hline
\end{tabular}

Table 2 shows that all success factors of business process improvement as suggested by Trkman have occurred in the implementation of the new business process as described in the case. This might answer how Ubaya could successfully deliver the expected benefits from changing the business process to issue the letter of assignment. Important remark to be learnt from this case is that although IT has an essential role in business process improvement, investing in IT does not automatically means guarantee performance improvements [10]. The key is to find a proper level of IT investment to support the organization's strategy.

\section{Significance and further study}

The case shows how Trkman's success factor framework can be used as a guideline to implement a business process improvement project in a higher education institution. It is hoped that such success story could provide insight to other institutions who wish to leverage their performance.

Interesting direction for further study is measuring the necessity level of each success factor. It is likely that some factors are more important than others. Such ranking is crucial especially when it is not possible to satisfy all success factors and thus need to sacrifice some less important success factors in order to satisfy the more critical success factors.

\section{Conclusions}

The project done in the case is considered successful as the new process able to produce significant improvements in all four dimensions: cost, quality, time, and flexibility. Further analysis shows that the business process implementation in the University of Surabaya satisfies all success factors in Trkman's framework. Compliance to all success factors in the framework explained how the University of Surabaya able to successfully completed the business process improvement project. Unfortunately, there is no indication on level of each factor's influence toward the project's 
success. Identification of each factor's necessity is a good direction for further study as it is important especially when the organization unable to satisfy all factors and thus need to select the most important factors to be prioritized.

\section{References}

1. S. Smirnov, H.A. Reijers, M. Weske, and T. Nugteren, "Business process model abstraction: a definition, catalog, and survey," Distributed and Parallel Databases, pp: 63-99, 2012.

2. S. Alter, "Information System Planning", Information Systems: The Foundation of E-Business $4^{\text {th }}$ edition, Chapter 11, Prentice Hall, New Jersey, 2002.

3. J.A. O’Brien and G.M. Marakas, "Information Technology as a Competitive Advantage”, Enterprise Information Systems $13^{\text {th }}$ Edition, Chapter 2, McGraw-Hill, 2007.

4. C. Ranganathana and J.S. Dhaliwal, "A Survey of Business Process Reengineering Practices in Singapore", Information \& Management, Vol. 39 No. 2, pp. 125-134, 2001.

5. H. Ahmad, A. Francis, and M. Zairi, "Business Process Reengineering: Critical Success Factors in Higher Education”, Business Process Management Journal, Vol. 13 No. 3, pp. 451-469, 2007.

6. A.R. Dennis, T.A. Carte, and G.G. Kelly, "Breaking the Rules: Success and Failure in Groupware-Supported Business Process Reengineering", Decision Support Systems, Vol. 36, pp. 31- 47, 2003.

7. Y. Malhotra, "Business Process Redesign: An Overview," IEEE Engineering Management Review, Vol. 26, No. 3, Fall 1998.

8. P. Trkman, "The critical success factors of business process management," International Journal of Information Management, Vol. 30, pp. 125-134, 2010.

9. H.A. Reijers and S.L. Mansar, "Best Practices in Business Process Redesign: an Overview and Qualitative Evaluation of Successful Redesign Heuristics”, Omega, Vol. 33, pp. 283 - 306, 2005.

10. M. Luca, "Business Process Reengineering," International Conference "Risk in Contemporary Economy," 15 ${ }^{\text {th }}$ Edition, Romania, 2014. 


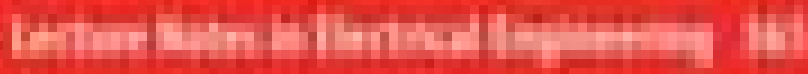

ARAr

Withath

Rinitu

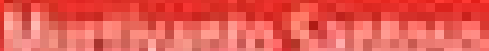

in

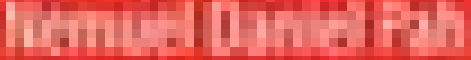

Hint

Proceedings of Second Intemational Conference on Electrical Systems, Technology and liformation 2015 (ICESTI 2015) 


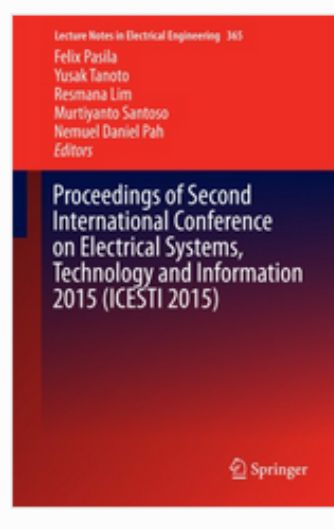

(c) 2016

Proceedings of Second International Conference on Electrical Systems, Technology and Information 2015 (ICESTI 2015)

Editors (view affiliations)

Felix Pasila, Yusak Tanoto, Resmana Lim, Murtiyanto Santoso, Nemuel Daniel Pah

Conference proceedings

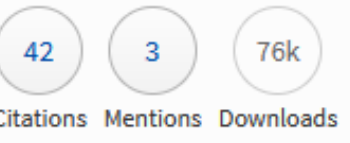

Part of the Lecture Notes in Electrical Engineering book series (LNEE, volume 365) 


\section{Editors and affiliations}

\author{
Felix Pasila \\ Yusak Tanoto \\ Resmana Lim \\ Murtiyanto Santoso \\ Nemuel Daniel Pah
}

1. Electrical Engineering Department, Petra Christian University, Surabaya, Indonesia

2. Petra Christian University, Surabaya, Indonesia

3. Electrical Engineering Department, Petra Christian University, Surabaya, Indonesia

4. Electrical Engineering Department, Petra Christian University, Surabaya, Indonesia

5. University of Surabaya, Surabaya, Indonesia

\section{Bibliographic information}

\section{Book Title \\ Proceedings of Second International Conference on Electrical Systems, Technology and Information 2015 (ICESTI 2015)}

Series Abbreviated Title Lect. Notes Electrical Eng.

\section{Publisher Name}

Springer, Singapore

Softcover ISBN

978-981-13-5739-8

Series E-ISSN

1876-1119

Number of Illustrations

$272 \mathrm{~b} /$ w illustrations, 112 illustrations in colour
Editors

Felix Pasila

Yusak Tanoto

Resmana Lim

Murtiyanto Santoso

Nemuel Daniel Pah

DOI

https://doi.org/10.1007

/978-981-287-988-2

eBook Packages

Engineering

Engineering_(R0)

eBook ISBN

978-981-287-988-2

Edition Number

Topics

Robotics and Automation

Energy Systems

Electrical Engineering

Information Systems and

Communication Service
Series Title

Lecture Notes in Electrical

Engineering

Copyright Information

Springer Science+Business Media Singapore 2016

Hardcover ISBN

978-981-287-986-8

Series ISSN

1876-1100

Number of Pages

XIV, 692

Buy this book on publisher's site 


Table of contents (76 popers)
Front Matter
Poges i-xiv
Invited Speaker
Front Matter
Pages 1-1
Computational Intelligence Based Regulation of the DC Bus in the On-grid Photovoltaic System
Mauridhi Hery Purnomo, lwan Setiowan, Ardyono Priyadi
Pages 3-15
Virtual Prototyping of a Compliant Spindle for Robotic Deburring
Giovonni Berselli, Morcello Pellicciori, Gobriele Bigi, Angelo 0. Andrisono
Pages 17-30
A Concept of Multi Rough Sets Defined on Multi-contextual Information Systems
Rolly Intan
Pages 31-44

\section{Technology Innovation in Robotics Image Recognition and Computational Intelligence Applications}

Front Matter

Pages 45-45

Coordinates Modelling of the Discrete Hexapod Manipulator via Artificial Intelligence

Felix Pasile, Roche Alimin

Poges 47-53

An Object Recognition in Video Image Using Computer Vision

Sang-gu Kim, Seung-hoon Kang, Joung Gyu Lee, Hoon Joe Lee

Pages 55-63

Comparative Study on Mammogram Image Enhancement Methods According to the Determinant of Radiography Image Quality

Erne Alimudin, Henung Adi Nugroho, Teguh Bharata Adji

Pages 65-73

Clustering and Principal Feature Selection Impact for Internet Traffic Classification Using K-NN

Trienggoro Wiredinete, P. Adi Suryaputra

Pages 75-81 
Altitude Lock Capability Benchmarking: Type 2 Fuzzy, Type 1 Fuzzy, and Fuzzy-PID with Extreme Altitude Change as a Disturbance

Hendi Wicaksono, Yohanes Gunawen, Cornelius Kristento, Leonardie Haryanto

Pages 83-89

Indonesian Dynamic Sign Language Recognition at Complex Background with 2D Convolutional Neural Networks

Nehemie Sugiento, Elizabeth Irenne Yuwono

Pages 91-98

Image-Based Distance Change Identification by Segment Correlation

Nemuel Deniel Pah

Pages 99-106

Situation Awareness Assessment Mechanism for a Telepresence Robot

Petrus Santoso, Hendry Khoswanto

Pages 107-113

Relevant Features for Classification of Digital Mammogram Images

Erno Alimudin, Henung Adi Nugroho, Teguh Bharato Adji

Pages 115-122

Multi-objective Using NSGA-2 for Enhancing the Consistency-Matrix

Abbo Suganda Girseng, Sfenriento, Jarot S. Suroso

Pages 123-129

Optimization of AI Tactic in Action-RPG Game

Kristo Redion Purbe

Pages 131-137

Direction and Semantic Features for Handwritten Balinese Character Recognition System

Luh Putu Ayu Prapitasari, Komeng Budiarta

Pages 139-147

Energy Decomposition Model Using Takagi-Sugeno Neuro Fuzzy

Yusak Tanoto, Felix Pasile

Pages 149-154

Odometry Algorithm with Obstacle Avoidance on Mobile Robot Navigation

Hendry Khoswanto, Petrus Santoao, Resmane Lim

Pages 155-161 


\section{Technology Innovation in Electrical Engineering, Electric Vehicle and Energy Management}

Front Matter

$\mathrm{PDF} \unrhd$

Pages 163-163

Vision-Based Human Position Estimation and Following Using an Unmanned Hexarotor Helicopter

Jung Hyun Lee, Taeseok Jin

Pages 165-172

The Role of Renewable Energy: Sumba Iconic Island, an Implementation of 100 Percent Renewable Energy by 2020

Abroham Lomi

Pages 173-184

Electromechanical Characterization of Bucky Gel Actuator Based on Polymer Composite PCL-PUCNT for Artificial Muscle

Yudan Whulenza, Andika Pradityo Hediputra, Felix Pasile, Sugeng Supriadi

Pages 185-192

A Single-Phase Twin-Buck Inverter

Henny H. Tumbelake

Pages 193-202

Performance Comparison of Intelligent Control of Maximum Power Point Tracking in Photovoltaic System

Daniel Martomenggolo Wonohadidjojo

Pages 203-213

Vehicle Security and Management System on GPS Assisted Vehicle Using Geofence and Google Map Lonny Agustine, Egber Pongalielo, Hertono Pranjoto Pages 215-226

Security and Stability Improvement of Power System Due to Interconnection of DG to the Grid Ni Putu Agustini, Leuhil Mahfudz Heyusman, Teufik Hideyet, I. Made Wartane

Pages 227-237

Solar Simulator Using Halogen Lamp for PV Research

Aryuanto Soetedjo, Yusuf lamail Nakhoda, Abraham Lomi, Teguh Adi Suryanto

Pages 239-245

Artificial Bee Colony Algorithm for Optimal Power Flow on Transient Stability of Java-Bali $500 \mathrm{KV}$

Irrine Budi Sulistiaweti, M. Ibrahim Asheri

Pages 247-255

Sizing and Costs Implications of Long-Term Electricity Planning: A Case of Kupang City, Indonesia

Daniel Rohi, Yusak Tanoto

Pages 257-262

Dynamic Simulation of Wheel Drive and Suspension System in a Through-the-Road Parallel Hybrid Electric Vehicle

Mohamed Yamin, Cokorde P. Mehenderi, Resyid H. Sudono

Pages 263-270 
A Reliable, Low-Cost, and Low-Power Base Platform for Energy Management System

Henry Hermawan, Edward Oesnawi, Albert Darmaliputre

Pages 271-277

Android Application for Distribution Switchboard Design

Julius Sentosa Setiodji, Kevin Budihergono, Petrus Santoso

Pages 279-286

\section{Technology Innovation in Electronic, Manufacturing, Instrumentation and Material Engineering}

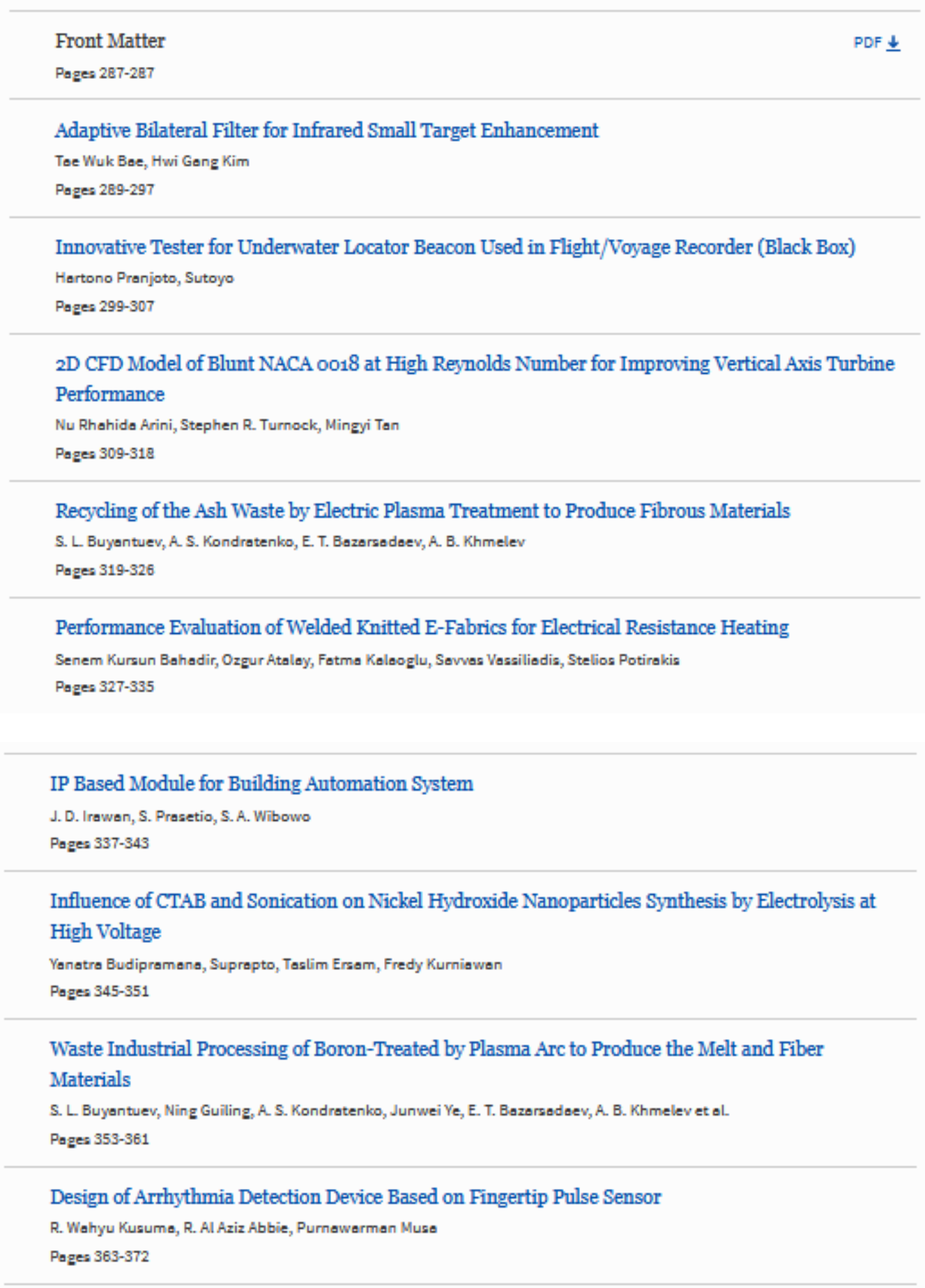


Analysis of Fundamental Frequency and Formant Frequency for Speaker 'Makhraj' Pronunciation with DTW Method

Muhammed Subali, Mifteh Andriansyah, Christanto Sinambele

Pages 373-382

Design and Fabrication of " $\mathrm{Ha} 0$ " Shape-Slot Microstrip Antenna for WLAN $2.4 \mathrm{GHz}$

Srisento Sotyohadi, Sholeh Hadi Pramono, Moechammed Saroaa

Pages 383-391

Investigation of the Electric Discharge Machining on the Stability of Coal-Water Slurries

S. L. Buyantuev, A. B. Khmelev, A. S. Kondratenko, F. P. Boldynovo

Pages 393-399

A River Water Level Monitoring System Using Android-Based Wireless Sensor Networks for a Flood Early Warning System

Riny Sulistyowati, Heri Agus Sujono, Ahmad Khamdi Musthofo

Pages 401-408

The Influence of Depth of Cut, Feed Rate and Step-Over on Surface Roughness of Polycarbonate Material in Subtractive Rapid Prototyping

The Jaye Suteja

Pages 409-414

Adaptive Cars Headlamps System with Image Processing and Lighting Angle Control

William Tondy Prasetyo, Petrus Santoso, Resmana Lim

Pages 415-422

Changes in the Rheological Properties and the Selection of a Mathematical Model of the Behavior of Coal-Water Slurry During Transport and Storage

S. L. Buyantuev, A. B. Khmelev, A. S. Kondratenko

Pages 423-428

Design of a Fetal Heartbeat Detector

Nur Sultan Solahuddin, Sri Poernomo Sari, Poulus A. Jambormies, Johan Harlan

Pages 429-435

\section{Technology Innovation in Internet of Things and Its Applications}

Front Matter

$\mathrm{PDF} \pm$

Pages 437-437

Network Traffic and Security Event Collecting System

Hee-Seung Son, Jin-Heung Lee, Toe-Yong Kim, Sang-Gon Lee

Pages 439-446

Paper Prototyping for BatiKids: A Technique to Examine Children's Interaction and Feedback in Designing a Game-Based Learning

Hestiesari Rente, Heidi Schelhowe, Michael Lund

Pages 447-455

Tracing Related Scientific Papers by a Given Seed Paper Using Parscit

Resmana Lim, Indra Ruslen, Hensin Susetya, Adi Wibowo, Andreas Hendojo, Reymond Sutjiedi

Pages 457-464 
Factors Affecting Edmodo Adoption as Online Learning Medium

lwa Sungkono Herlombengkoro, Trianggoro Wiradinato

Pages 465-473

Principal Feature Selection Impact for Internet Traffic Classification Using Naīve Bayes

Adi Suryoputro Paromito

Pages 475-480

Study on the Public Sector Information (PSI) Service Model for Science and Technology Domain in South Korea

Yong Ho Les

Pages 481-486

Digital Natives: Its Characteristics and Challenge to the Library Service Quality

Siene Halim, Felecia, Inggrid, Dian Wulendari, Demmy Kasih

Pages 487-494

\section{Technology Innovation in Internet of Things and Its Applications}

Web-Based Design of the Regional Health Service System in Bogor Regency

B. Sunderi, Revide Iriana, Bertilie Line Kuarina

Pages 495-500

Security Handwritten Documents Using Inner Product

Syaifudin, Dian Pratiwi

Pages 501-509

Augmented Reality Technique for Climate Change Mitigation

Ruswendi Tohrir

Pages 511-519

Cyber Security for Website of Technology Policy Laboratory

Jorot S. Suroao

Pages 521-528

TAM-MOA Hybrid Model to Analyze the Acceptance of Smartphone for Pediatricians in Teaching Hospital in Indonesia

Oktri Mohemmed Firdaus, Nanen Sekerwana, T. M. A. Ari Samedhi, Kah Hin Chai

Pages 529-536

Development of the Remote Instrumentation Systems Based on Embedded Web to Support Remote Laboratory

F. Yudi Limpreptono, Irmelia Suryeni Foredise

Pagea 537-543

Enhancing University Library Services with Mobile Library Information System

Singgih Lukman Anggane, Stephanus Eko Wahyudi

Pages 545-552 
Multi Level Filtering to Classify and Block Undesirable Explicit Material in Website

Mohammed lqbal, Hifshan Riesvicky, Hasme Resjid, Yulia Charli

Pages 553-563

Query Rewriting and Corpus of Semantic Similarity as Encryption Method for Documents in Indonesian Language

Detty Purnamesari, Rini Arianty, Diene Tri Susetianingties, Reni Dieh Kusumawati

Pages 565-571

Securing Client-Server Application Design for Information System Inventory

Ibnu Gunawan, Djoni Horyadi Setiebudi, Agustinus Noertjohyono, Yongky Hermawen

Page: 573-580

\section{Technology Innovation in Information, Modelling and Mobile}

\section{Applications}

Front Matter

PDF $\unrhd$

Pages 581-581

Analyzing Humanitarian Logistic Coordination for Disaster Relief in Indonesia

Tonti Octavio, I. Gede Agus Widyadano, Herry Christion Polit

Pages 583-5es

Surakarta Cultural Heritage Management Based on Geographic Information Systems

Ery Dewayani, M. Viny Christanti

Pages 5e9-598

Gray Code of Generating Tree of $n$ Permutation with $m$ Cycles

Sulistyo Puspitodjati, Henny Widowati, Crispina Pardede

Pages 599-605

Android and iOS Hybrid Applications for Surabaya Public Transport Information

Djoni Heryadi Setiabudi, Ledy Joanne Tjahyane

Pages 607-617

Games and Multimedia Implementation on Heroic Battle of Surabaya: An Android Based Mobile Device Application

Andreas Handojo, Resmana Lim, Justinus Andjarwirawon, Sondy Sunaryo

Pages 619-629

Streamlining Business Process: A Case Study of Optimizing a Business Process to Issue a Letter of Assignment for a Lecturer in the University of Surabaya

S. T. Jimmy

Pages 631-637

Design of Adventure Indonesian Folklore Game

Kortiko Gunadi, Liliana, Harvey Tjahjono

Pages 639-647

Measuring the Usage Level of the IE Tools in SMEs Using Malcolm Baldrige Scoring System

I. Nyoman Sutapo, Togas W. S. Panjaitan, Joni Rahardjo

Pages 649-658 
Enumeration and Generation Aspects of Tribonacci Strings

Mauker, Asep Juerne, Djoti Keremi

Pages 659-667

A Leukocyte Detection System Using Scale Invariant Feature Transform Method

Lina, Budi Dharmewan

Pages 669-674

The Diameter of Enhanced Extended Fibonacci Cube Interconnection Networks

Ernestuti, Mufid Nilmade, Rovi Salim

Pages 675-683

Prototype Design of a Realtime Monitoring System of a Fuel Tank at a Gas Station Using an Android-Based Mobile Application

Riny Sulityowati, Bayu Bhahtra Kurnia Rafik

Pagea 685-692 